\title{
Hanefî Fıkıh Literatüründe Gelenek Oluşturan Kayıp Bir Metin: Muhtasarü'l-Kerhî*
}

\author{
Orhan Ençakar**
}

\section{A Canonical Lost Text in the Literature of the Hanafi Fiqh: Mukhtașar al-Karkhi}

Mukhtasars have been preferred in the teaching of Islamic law because they were simply short and concise form of legal problems (masāil). These books became the primary sources in conveying the madhhab masăil to the following generations after a certain point in history. From among them, al-Mukhtașar by alKarkhī, the then head of the Hanafi fuqahä' in Baghdad and one of the earliest authors of mukhtașar, was very important. This work served as the main source of Qudūrìs al-Mukhtașar which was an exemplary text for the mukhtașars of the Hanafi madhhab during the classical period. While Karkhîs thoughts in legal theory had an impact on the usūl al-fiqh of the madhhab, his al-Mukhtașar also influenced the articulation of the furū' fiqh through Qudūrìs al-Mukhtașar. It thus became a guiding text for following mukhtașars of the madhhab in the classical period.

Keywords: al-Karkhī, al-Mukhtașar, Hanafiyya, formative period

\section{Giriş}

Hanefî mezhebinin teşekkül sürecini tamamladığı kabul edilen IV. (X.) asrın ilk yarısında kaleme alınan muhtasar metinlerin mezhep mesâilini sonraki nesillere aktarmada önemli bir rol oynadığı; mezhep imamları tarafından yazılmış fıkıh kitaplarının söz konusu asırdan itibaren özellikle tedris

* Bu makale "Kerhî̉nin el-Muhtasar'ının Hanefî Muhtasar Geleneğine Etkisi: Kudûrînnin Muhtasar’ının İcâre Bölümü Çerçevesinde" isimli yüksek lisans tezim (Marmara Üniversitesi Sosyal Bilimler Enstitüsü, 2013) esas alınarak hazırlanmıştır. Makaleyi okuyarak katkıda bulunan editör ve hakemlere, özellikle de makalenin konusu ve başlı̆̆ hakkındaki teklifleri için Dr. Ali Hakan Çavuşoğlu'na teşekkür ederim.

** Araştırma Uzmanı, Türkiye Diyanet Vakfı İslâm Araştırmaları Merkezi (İSAM). 
alanındaki merkezî konumlarını bu muhtasarlara terkettikleri bilinmektedir. Meselâ Şeybânînin (ö. 189/805) el-Asl adlı ansiklopedik eserinin bir ihtisarı sayılan ${ }^{1}$ Hâkim Şehîd'in (ö. 334/945) el-Kâfìsi Mâverâünnehir'de el-Asl'ın yerini alacak kadar etkili olabilmiştir. Bu dönemin önemli muhtasarlarından bir diğeri de zamanında Bağdat Hanefîleri’nin reisi kabul edilen Ebü’l-Hasan Ubeydullah b. Hüseyin el-Kerhî̀nin (ö. 340/952) el-Muhtasar’’dır. Bu muhtasar için kitabın şârihlerinden Kudûrî (ö. 428/1037), Kerhînnin talebesi Ebû Ali eş-Şâş̧ı̀den (ö. 344/955) nakille, "Bu kitabı ezberleyen, ashabımızın (mezhebi) en iyi hıfzedeni, anlayan da ashabımızın (mezhebi) en iyi anlayanı olur" demektedir. ${ }^{2}$ Adı geçen iki muhtasarla birlikte mezhebin Mısır coğrafyasındaki temsilcisi Ebû Ca'fer et-Tahâvîye (ö. 321/933) ait el-Muhtasar Hanefî mezhebinin yayıldığ 1 üç farklı coğrafyada teşekkül döneminde telif edilen ilk muhtasarlar arasinda yer almaktadır.

Teşekkül döneminden sonra başlayan klasik dönemin bilinen ilk muhtasar çalışması ise Kudûrîye (ö. 428/1037) aittir. Onun telif ettiği el-Muhtasar’ın klasik dönem meşhur Hanefî fıkıh muhtasarları üzerindeki etkisi tartışmaya mahal bırakmayacak kadar açıktır. Teşekkül dönemi muhtasarlarından klasik dönem muhtasarlarına geçişi temsil eden ve bu iki dönem arasında bir köprü vazifesi gördüğü anlaşılan Kudûrînin, Kerhî gibi Irak Hanefî ekolüne mensup olması, Kerhînin üçüncü kuşak talebeleri arasında yer alıp, onun el-Muhtasar'inı hocası Ebû Abdullah Muhammed b. Yahyâ el-Cürcânîden (ö. 398/10o8) okuması, daha sonra bu eser üzerine bir şerh yazıp, şerhin başında yukarıda zikredilen övgüleri aktarması kendi muhtasarını telif ederken Kerhînin el-Muhtasar'ını esas almış olabileceği ihtimalini gündeme getirmektedir. Bu amaçla her iki muhtasar arasında şekil ve muhteva yönünden yapılan inceleme sonucunda Kudûrînin muhteva ve özellikle mesâilin sunumundaki sistematik açısından Kerhî̀yi takip ettiği görülmüştür. Kerhî, bir taraftan usule dair görüşleriyle Hanefî mezhebi usûl-i fikıh anlayışının oluşumuna önemli katkılarda bulunurken, diğer taraftan fürû-i fikha dair telif ettiği el-Muhtasar’’ ile mezhebin bu alanda üretilen metinlerine muhteva ve sistematik açısından model oluşturan bir eser sunmuştur.

Makale, Kerhîye ait bu el-Muhtasar'in şekil ve muhteva açısından tahlilini konu edinmenin yanı sıra eserin klasik dönemin model metni Kudûrînin el-Muhtasar’ı ve onun vasitasıyla mezhebin diğer meşhur fikıh muhtasarları

1 el-Asl’ tahkikli neşreden Boynukalın, "Kâfî̀ incelendiğinde bu eserin öncelikle Asl’ın lafzını esas alıp onu özetlediği, sonra Şeybânînin ve kimi yerde diğer ilk dönem fakihlerinin eserlerinden nakillerde bulunduğu görülmektedir” demektedir (Boynukalın, İmam Muhammed b. Hasan eş-Şeybânî, s. 122).

Kudûrî, Şerhu Muhtasari'l-Kerhî, Köprülü Ktp., Fâzıl Ahmed Paşa, nr. 93, vr. ob. 
üzerinde muhteva ve sistematik açısından etkili olduğu tezini de savunmakta ve bu etkiyi yeri geldikçe örnekler üzerinden göstermeye çalışmaktadır. el-Muhtasar'ın şekil açısından tahlilinde eserin tamamı, muhteva açısından tahlilinde ise ağırlıklı olarak icâre bölümü esas alınmıştır. Bununla birlikte muhteva tahlili esnasında ele alınan konular diğer bazı bölümlerden de incelenerek daha geniş kapsamlı ve bol örnekli bir tahlil sunulmaya gayret edilmiştir. ${ }^{3}$ Müstakil bir nüshası bulunmayan el-Muhtasar'ın metnine, Kudûrî tarafından yapılan şerhin iki yazma nüshası ${ }^{4}$ içinde geçen metin parçaları ile yine bu şerhin bazı bölümleri üzerine yapılmış akademik çalışmalar ${ }^{5}$ üzerinden ulaşılmıştır.

\section{Ebü'l-Hasan el-Kerhî}

26o'ta (874) Irak’in Kerh-i Cüddân beldesinde doğan Ebü'l-Hasan Ubeydullah b. Hüseyin b. Dellâl b. Delhem el-Kerhî Bağdat'ta yaşamıştır. ${ }^{6}$ Bölgede ders halkası bulunan iki büyük Hanefî fakihi Kadı Ebû Hâzim (ö. 292/905) ve Ebû Saîd el-Berdaîdden (ö. 317/930) sonra Bağdat’ta Hanefî çevresine bağlı fakihlerin reisi haline gelmiştir.7 Devrin meşhur fakihleri ondan ders almış, ${ }^{8}$ yetiştirdiği öğrenciler dört bir yana yayılmış, birçoğu kadılık görevine getirilmiştir. ${ }^{9}$ Hanefî mezhebinin erken dönem biyografi yazarlarından Kadı Ebû Abdullah es-Saymerînin (ö. 436/1045) "Kerhî ve Ebû Hâzim hakkında bütün bildiklerimi zikredecek olsaydım ikisi hakkında ayrı bir kitap yazmam gerekirdi" demesine ${ }^{10}$ rağmen Kerhî hakkında günümüze ulaşan bilgiler çok sınırlıdır. Ömrünün sonuna doğru felç olan Kerhî tedris faaliyetinden

3 Erken dönem şerh anlayışında metin ve şerh, sınırları belirtilmeden iç içe verildiği gibi şerhe konu olan metin de tam olarak aktarılmadı̆̆ için Kerhîye ait ifadelerin nerede başlayıp nerede bittiğini tam olarak tespit etmek ve böylece el-Muhtasar'ın tamamını ortaya çıkarmak pek mümkün olmadığından, makalede Kerhînnin ifadelerinin daha rahat seçilebildiği bölümlerden biri olan icâre kısmı esas alınmıştır. Bununla birlikte yukarıda ifade edildiği üzere eser hakkında daha sağlıklı bir kanaat elde edebilmek için diğer bölümler de imkân nispetinde incelemeye tâbi tutulmuştur.

Süleymaniye Ktp., Damad İbrâhim Paşa, nr. 563; Köprülü Ktp., Fâzıl Ahmed Paşa, nr. 93.

5 Kudûrînin Şerhu Muhtasaril-Kerhî adlı eserinin bazı bölümleri üzerine yapılmış şu tahkikli çalışmalardan da faydalanılmıştır: Güney, "Kudûrînin 'Şerhu Muhtasari'lKerhî̀ Adlı Eserinin 'Siyer' Bölümünün Edisyon Kritiği”; Abdülmuhsin b. Abdullah, "Şerhu Muhtasari'l-Kerhî”; Âdil b. Abdullah, "Şerhu Muhtasari'l-Kerhî”.

6 Saymerî, Ahbâru Ebî Hanîfe, s. 167.

7 Saymerî, Ahbâru Ebî Hanîfe, s. 166.

8 Nedîm, el-Fihrist, III, 34-35.

9 Saymerî, Ahbâru Ebî̀ Hanîfe, s. 166.

10 Saymerî, Ahbâru Ebî Hanîfe, s. 167. 
çekilince, ders vermeyi talebesi Ebû Ali eş-Şâş̧îye (ö. 344/955), fetva vermeyi de diğer talebesi Ebû Bekir ed-Dâmegānîye bırakmıştır. ${ }^{11} 340$ (952) yılı Şâban ayı ortasında vefat eden Kerhînin cenaze namazını talebelerinden Kadı Ebû Temmâm Hasan b. Muhammed el-Hâşimî ez-Zeynebî kıldırmış, Hasan b. Zeyd mahallesinde Vâsitîn nehri kıyısındaki mescidinin yanına defnedilmiştir. ${ }^{12}$

\section{Muhtasarü'l-Kerhî}

Yukarıda ifade edildiği üzere el-Muhtasar'ın metni müstakil olarak mevcut değildir. ${ }^{13}$ Kerhî ile aynı dönemde yaşayan Tahâvî ve Hâkim Şehîd'in muhtasarları günümüze ulaşırken, mezhep içerisinde "meşâyih"14 adıyla ortaya çıkan ilk fakihler arasında yer alan ve Bağdat Hanefîleri’nin reisi ${ }^{15} \mathrm{kabul}$ edilen Kerhînin telif ettiği eserlerin bugüne ulaşmamasında onun i'tizâlî görüşlere sahip olmasının önemli bir etkisi olsa gerektir. ${ }^{16}$ Zira fikıh kitaplarında yer alan, ehl-i bidatın kelâma dair yazdığı eserlerin okunmaması ve elde bulundurulmaması gerektiği yönündeki fetvalarda Mu'tezile’ye ait eserler de sayılmaktadır. ${ }^{17}$ Mu'tezile’nin kelâma dair yazdığı eserlere karşı sergilenen bu tavır anlaşıldığı kadarıyla, i'tizâlî fikirleri bulunan Kerhî gibi bazı Hanefî fakihlerinin fikıh sahasında telif ettikleri eserleri de kapsamıştır. Bu eserler bugüne ulaşamamışsa bu durum, Kerhînin itikadî görüşleri başta olmak üzere birtakım olumsuz sebeplere bağlanabilir. ${ }^{18}$

11 Saymerî, Ahbâru Ebî Hanîfe, s. 169. Kerhînnin hayatı ve eserleri için bk. Ençakar, "Kerhî̀nin Muhtasar'”, s. 34-49; Apaydın, "Kerhî”, s. 285-87.

12 Saymerî, Ahbâru Ebî̀ Hanîfe, s. 167-68.

13 Sezgin, Târîhu't-türâsi'l-Arabî, I/3, s. 102. Suudi Arabistan Melik Faysal Merkezi'nde Kerhî adına kayıtlı birkaç muhtasar yazması görünmektedir, ancak bunlardan hiçbiri Kerhî̀nin el-Muhtasar’ı değildir (bk. Güney, 'Şerhu Muhtasari'l-Kerhî̀, s. 70).

14 Hanefî mezhebi içinde mezhep mesâilini değerlendirme, küllî kaide vazetme, içtihat ve tahriç melekesine sahip olma gibi bir dizi önemli meziyete sahip olmayı gerektiren ve genelde bir bölgede belli bir fakihin etrafında toplanan veya benzer fikhî tercihlere sahip fakihler grubunu ifade etmekte kullanılan "meşâyih" kavramının ortaya çıkışıyla ilgili olarak bk. Kaya, "Hanefî Mezhebinde Nevâzil Literatürünün Doğuşu”, s. 33-39; Bardakoğlu, "Hanefî Mezhebi”, s. 9-10.

Bir coğrafyada "bir mezhep çevresindeki fakihlerin merkezi şahsiyeti olmak" şeklinde tercüme edilebilecek ifade kalıbının (intehet ileyhi riyâsetü) anlamı ve önemi hakkında bk. Makdisi, Ortaçă̆’da Yüksek Öğretim, s. 202-205.

16 Kerhî̉nin itikadî mezhebi için bk. Ençakar, “Kerhînnin Muhtasar'ı”, s. 44-46.

17 Şeyh Nizâm v.dğr., el-Fetâvầl-Hindiyye, V, 377.

18 Bağdat'taki ehl-i re'y ve ehl-i hadis çekişmeleri ve Hanefîler'in bu süreçteki durumu için bk. Özen, Ebû Mansûr el-Mâtürîdînin Fıkıh Usûlünün Yeniden İnşası, s. 161-92; Bedir, “Hanefî Mezhebinin Abbâsî Bağdat’ında Yükselişi ve Zayıflaması”, s. 621-32. 


\section{A) Eserin Telif Tarihi ve Kaynakları}

Kerhînin el-Muhtasar’ını ne zaman telif ettiği tam olarak bilinmemekle birlikte, bu eserinde diğer iki eseri el-Câmiu's-sagìr ${ }^{19}$ ve el-Câmiu'l-kebîr'den ${ }^{20}$ bahsetmesi el-Muhtasar’ını onlardan daha geç bir dönemde telif ettiğini göstermektedir. el-Muhtasar'ın kaynaklarını çoğunlukla mezhep imamlarından nakledilen zâhirürr-rivâye (Usûl ve Câmiayn) ve gayru zâhirìr-rivâye (Emâlı̂ ve Nevâdir) mesâili oluşturmaktadır. Ayrıca Alâeddin es-Semerkandî (ö. 539/1144) Kerhînin Muhtasar’’nı esas alarak telif ettiği Tuhfetül-fukahầ isimli eserinde ${ }^{21}$ talâkla ilgili bir meselede Kerhînin Tahâvî hakkında, "Bu meselede zikrettiği Ebû Hanîfe’nin görüşüdür” dediğini nakletmektedir. ${ }^{22}$ Kerhînin el-Muhtasar'ında yer alan bu ifadeden ${ }^{23}$ onun Tahâvînin el-Muhtasar'ını gördüğg̈ ve aşağıda geleceği üzere iki muhtasar arasında şekil ve muhteva açısından yer yer ortak noktalar bulunduğu görülse de, iki muhtasar arasında ağırlıklı olarak icâre bölümü üzerinden yapılan örnek karşılaştırma neticesinde Kerhînin muhteva ve özellikle mesâilin sunumundaki sistematik açısından Tahâvînin el-Muhtasar'ında var olandan çok daha farklı bir üslûp geliştirdiği tespit edilmiştir. ${ }^{24}$

\section{B) Eserin Şekil/İç Tasnif Açısından Tahlili}

İlk dönemde "kitâb" adıyla yapılan fikıh tedvinlerinde eser "namaz, zekât, nikâh, alışveriş" gibi sadece bir konuya tahsis edilirken aynı dönemde telif edilen "câmi" ve sonraki dönemlerde telif edilen "muhtasar" tarzı eserlerde fıkhın bütün konuları belli bir tertip içinde peş peşe sıralanarak aynı kitapta yer almıștır. Fıkhın bütün konularının bir araya getirildiği bu "câmi" ve "muhtasar" türü eserlerde mevcut olan konu tertibi farklı coğrafya ve telif geleneklerine göre kısmî değişiklikler gösterse de, ibadet-muâmelât şeklindeki ikili ayırıma hemen bütün fikıh eserlerinde riayet edilmiştir. ${ }^{25}$ Özellikle

19 Kudûrî, Şerhu Muhtasaril-Kerhî, Süleymaniye Ktp., Damad İbrâhim Paşa, nr. 563, vr. $263^{\mathrm{a}}$.

20 Kâtib Çelebî, Keşfü̈z-zunûn, I, 570.

21 Tuhfetül-fukahâ' yaygın kanaatin aksine, Kudûrî̀nin değil Kerhînin el-Muhtasar'ı esas alınarak telif edilmiştir (bk. Ençakar, "Kerhî̀nin Muhtasar'ı', s. 21-24).

22 Semerkandî, Tuhfetül-fukahâ', II, 174.

23 Kudûrî, Şerhu Muhtasaril-Kerhî, nr. 563, vr. 143 . Kerhînin “Tahâvînin zikrettiği” dediği bu mesele Tâhâvînin el-Muhtasar'ında yer almaktadır (Bk. el-Muhtasar, s. 192-93).

24 Kerhînnin el-Muhtasar'ının icâre bölümünün şekil ve muhtevası ile ilgili olarak bk. Ençakar, "Kerhî̉nin Muhtasar'i”, s. 75-104.

25 Fürû-i fıkıh kitaplarının sistematiği için bk. Aybakan, "Furu' Fıkıh Sistematiği Üzerine", s. 5-32. Hanefî mezhebi fikıh kitaplarının tertibiyle ilgili olarak ayrıca bk. Ebû Süleyman, Tertîbü'l-mevzûâti'l-fikhiyye, s. 15-42. 
ibadetle ilgili konular bütün muhtasarlarda "tahâret, namaz, zekât, oruç ve hac" şeklinde aynı olmuş ve muhtasarların başında ilk önce ibadetle ilgili mesâile yer verilmiștir. ${ }^{26}$ İbadetler dışındaki konular ise Hanefî mezhebi içinde birkaç farklı telif geleneğine göre sıralanmıştır: Şeybânînin telif ettiği el-Câmiu's-sagìr'deki iç tasnifi esas alan el-Hidâye'nin metni el-Bidâye ile bu konuda onu takip eden muhtasarlarda ibadet bahislerinin peşinden öncelikle "nikâh, yemin, hadler ve siyer" konuları gelirken, Kudûrînin el-Muhtasar'ı ve onun iç tasnifini takip eden muhtasarlarda ise ibadet bahislerinden sonra alışveriş ve onunla alâkalı diğer konular gelmektedir.

\section{Bölümlerin/Kitapların Tertibi}

Kudûrî, Kerhînin el-Muhtasar’ina yapmış olduğu şerhin başında, elMuhtasar’ın tertibinin değişik olduğunu, zira Kerhînin eseri önce kısa bir metin olsun diye telif etmeye başladığını; fakat ibadet bahisleri bittikten sonra esere yeni bölümler eklediğini ve rehin bahsinden sonra da eseri iyice genişlettiğini söyler. ${ }^{27}$ Kudûrînin bu ifadelerinden anlaşıldığı kadarıyla Kerhî̀nin el-Muhtasar’ı mesâil açısından başı-sonu birbiriyle uyumlu bir eser olmayıp, mesâili baştan sona doğru giderek genişleyen ve bu sebeple diğer klasik muhtasarlarda bulunan bazı bölümleri ve babları içermeyen eksik kalmış bir telif yapısındadır. Kudûrî, eseri bölümler arasında hacim dengesini gözeterek şerhetmeye çalıştı̆̆ını ve buna göre Kerhînnin ihmal ettiği bölüm ve mesâili gerekli yerlere eklediğini belirtmektedir. ${ }^{28}$ Alâeddin es-Semerkandî, Kerhî̀nin el-Muhtasar'mı esas alarak telif ettiği Tuhfetü'l-fukahâ’nın sonuna

26 Bu konuda en farklı tasnif kendisinin de ifade ettiği üzere Molla Hüsrev’e (ö. 885/148o) aittir (Dürerü’l-hükkâm, I, 3). Gurerü'l-ahkâm isimli muhtasarında ibadet konularının peşine "udhiye, sayd, zebâih, cihâd, ihyâ-yi mevât, kerâhiye" konularını ekleyen Molla Hüsrev diğer muhtasarlardan daha farklı bir tasnif benimsemiştir. Esere hâşiye yazanlardan Nûh Efendi (ö. 1070/1660) bu konuya dikkat çekip Molla Hüsrev'in konu tertibinde diğer eserlerden farklı bir yol takip ettiğini (Netâicü’n-nazar, Süleymaniye Ktp., Esad Efendi, nr. 653, 220 ${ }^{\text {b }}$ ) ve önce sırf Allah hakk1, sonra Allah hakkı galip gelen, ardından kul hakkı galip gelen ve en son sırf kul hakları şeklinde bir konu tertibi yaptığını söylemektedir (Netâicün-nazar, Süleymaniye Ktp., Esad Efendi, nr. 654, 122 ${ }^{\mathrm{a}}$ ).

27 Kudûrî, Şerhu Muhtasari'l-Kerhî, nr. 563, vr. $1^{\mathrm{b}}$.

28 Kudûrî, Şerhu Muhtasari'l-Kerhî, nr. 563, vr. $1^{\mathrm{b}}$. Kudûrî şerhe eklediği bölümlerin bazılarını, "Bu baba eklenenler" (مما يلحق بهذا الباب) şeklinde ifade etse de (örnek olarak bk. Abdülmuhsin b. Abdullah, "Şerhu Muhtasari'l-Kerhî”, s. 47, 63, 613, 659, 785; Âdil b. Abdullah, "Şerhu Muhtasari'l-Kerhî”, s. 135) hepsini açıkça söylememiştir. Bu sebeple eklediği mesâil ve kitapların hepsini net olarak tespit etmek mümkün değildir. Bunların bir kısmı bazı karinelerle belirlenebilmektedir. Meselâ Kudûrînin Kitâbü’lHudûd'un başından "bâbü sıfati'z-zinâya" kadar geçen bölümde (Âdil b. Abdullah, "Şerhu Muhtasari'l-Kerhî”, s. 81-97) Kerhînnin el-Muhtasar'ından hiçbir alıntı yapmaması buraya kadar olan kısmı kendisinin eklediği izlenimini vermektedir. 
el-Muhtasar'da bulunmayan şu sekiz bölümü eklemiştir: "Sebak, mefkūd, lakīt-lukata, hünsâ, şehâdât, şehâdâttan rücû́, edebüll-kādî ve vakıf-sadaka."

Kûdûrînnin șerhini esas alarak Kerhînnin el-Muhtasar’ı üzerine et-Tecrîd ve el-Îzâh adında iki farklı şerh çalı̧̧ması yapan Rükneddin el-Kirmânînin (ö. 543/1149) eserde Şeybânînin (el-Câmiu’s-sagìr'deki) tertibinden farklı bir tertip benimsendiğini söylemesi ${ }^{29}$ mütekaddimîn Hanefî fukahasının daha çok el-Câmiu's-sagir'deki tertibe riayet ettiğini göstermektedir. Meselâ müteahhir dönem Hanefî fikhının en çok ilgi gören eserlerinden el-Hidâye’nin müellifi Merginânî (ö. 593/1197) el-Câmiu's-sagìr ile Kudûrînin el-Muhtasar'ını bir araya getirerek telif ettiği el-Hidâye'nin metni Bidâyetüll-mübtedîde elCâmiu's-sagìr tertibini esas almıştır. ${ }^{30}$

el-Muhtasar diğer muhtasarlarda olduğu gibi "tahâret, namaz, zekât, oruç, hac" mesâilinin yer aldığı ibadet konularıyla başlar. İbadet konularında tek farklılık diğer muhtasarlarda "kitâbü's-salât"ın altında bir bab olarak ele alınan cenaze mesâilinin burada "kitâbü’l-cenâiz" adı altında ayrı bir bölümde işlenmiş olmasıdır. Ayrıca el-Asl ve onun ihtisarı sayılan Hâkim Şehîd'in el-Kâfìsinde tahâret konuları "kitâbü's-salât" in içinde yer alırken Kerhî bu konuları Tahâvî gibi "Kitâbü’t-Tahârât" adıyla ayrı bir bölümde ele almıştır. ${ }^{31}$

Hanefî̀ mezhebi muhtasarlarında konular, ibadet bölümlerinden sonra alışveriş veya nikâh mesâilinin ele alınması şeklinde iki farklı tertibe göre işlenmektedir. Şeybânî̉nin el-Asl’ında, Tahâvî, Kerhî, Kudûrî, Mevsılî (ö. 683/1284) ve İbnü’s-Sââtînin (ö. 694/1295) muhtasarlarında ibadet konularından sonra önce alışveriş ile başlayan muâmelât konuları gelirken, el-Câmiu's-sagìr ve onun iç tertibi esas alınarak hazırlanan el-Hidâye, el-Vikāye, en-Nukāye, Kenzü̉d-dekäik, Tenvîrüll-ebsâr ve Mülteka'l-ebhur'da ise önce nikâh ile başlayan münâkehat konuları gelmektedir. Kerhînnin el-Muhtasar'ında ise ibadet konularından sonra ilk önce alışveriş konusu işlenip hemen ardından nikâh konusuna geçilerek diğer muhtasarların hiçbirinde bulunmayan bir iç tertibe gidilmiş ve böylece alışveriş kitabı ile nikâh kitabı ardarda getirilmiştir. Nikâh ve talâk konularının peşinden de el-Câmiu's-sagìr'de olduğu gibi "itâk" ve "eymân" bahislerine geçen Kerhî daha sonrasında muâmelâtın diğer bir kısmına yer vermiş, arada "sayd, zebâih, udhiye, gasb, diyet, cinâyât, hudûd" bahislerini işledikten sonra "hibe, vedîa, âriye" konularına geçmiş, "dava" ve "beyyinât" konularından sonra da "vekâlet, kefâlet, havâle" gibi muâmelâtla alâkalı diğer konulara yer vermiştir. el-Muhtasar'ın sonunda

29 Kirmânî, el-Îzâh, Süleymaniye Ktp., Cârullah Efendi, nr. 586, vr. $1^{\mathrm{b}}$.

30 Kâtib Çelebî, Keş̧ü̈z-zunûn, I, 227.

31 Tahâvî, el-Muhtasar, s. 15-23; Kudûrî, Şerhu Muhtasari'l-Kerhî, nr. 93, vr. $2^{\mathrm{a}}-31^{\mathrm{b}}$. 
keffârât konularını içeren ayrı bir bölüm vardır. Diğer muhtasarlarda ise keffârât konuları ilgili bölümlerin içerisinde zikredilmiştir. el-Muhtasar'da daha evvel zikredilen "sebak, mefkūd, lakīt-lukata, şehâdât, şehâdâttan rücû, edebü'l-kādî, vakıf, ferâiz” gibi bazı önemli bölümler bulunmamaktadır.

Kerhînin el-Muhtasar'ında yer alan bölümlerin diğer muhtasarlara nispeten daha düzensiz olduğu görülmektedir. Bunda kitabın parça parça telif edilmiş olmasının bir etkisi olsa gerektir. Bununla birlikte eserin iç tasnifi bazı yönlerden Tahâvînin el-Muhtasar’ı ile benzeşmektedir. Kerhînnin tamamlayamadığı bu el-Muhtasar’’nda bulunmadığını söylediğimiz "mefkūd, şehâdât, şehâdâttan rücû, edebü’l-kādî” gibi bölümlerin Tahâvîye ait $e l$ Muhtasar'ın sonunda yer alması Kerhînin eserin iç tasnifini oluştururken Tahâvîden istifade ettiğine bir işaret kabul edilebilir. ${ }^{32}$

Kudûrî ve sonrasında yazılan meşhur metinlerin iç tasnif açısından Kerhîden etkilenmedikleri açıktır. Bu konuda yukarıda geçtiği üzere daha çok el-Câmiu's-sagì' in tertibi etkili olmuştur. el-Muhtasar'da yer alan bölümlerin tablo halinde sıralaması şöyledir:33

\begin{tabular}{|c|c|c|c|}
\hline No & Kitap İsimleri & No & Kitap İsimleri \\
\hline 1 & Kitâbü’t-Tahâre & 24 & Kitâbüd-Diyât \\
\hline 2 & Kitâbü’s-Salât & 25 & Kitâbü'l-Cinâyât ${ }^{34}$ \\
\hline 3 & Kitâbü’l-Cenâiz ${ }^{35}$ & 26 & Kitâbü'l-Hudûd \\
\hline 4 & Kitâbü’z-Zekât & 27 & Kitâbü's-Serika ve kat'u’t-tarîk \\
\hline 5 & Kitâbü’s-Siyâm & 28 & Kitâbü'l-Hibe \\
\hline 6 & Kitâbü’l-Menâsik & 29 & Kitâbü’l-Vedîa \\
\hline 7 & Kitâbü’l-Büyû́ & 30 & Kitâbü’l-Âriye \\
\hline
\end{tabular}

32 Tahâvî ise el-Muhtasar'inı hazırlarken dayısı Ebû İbrâhim İsmâil b. Yahyâ elMüzenînin (ö. 264/878) Şâfiî mezhebi fikhına dair telif ettiği el-Muhtasar'daki iç tertibi esas almıştır (Krş. Tahâvî, el-Muhtasar, s. 445-76; Müzenî, Muhtasarüll-Müzenî, s. 437-48).

el-Muhtasar'ın içindeki kitapların sıralaması Kudûrî şerhinden çıkartılmıştır (Kudûrî, Şerhu Muhtasaril-Kerhî, nr. 563). Kitapların belirlenmesi konusunda ayrıca Güney'in çalışmasından yer alan tablodan da yararlanılmıştır (Güney, "Şerhu Muhtasari'lKerhî”, s. 93-94).

34 Kerhînnin el-Muhtasar'ı esas alınarak telif edilen Tuhfetü'l-fukahâ'da cinâyât bahsi "kitâbü’d-diyât" altında işlenmektedir (Semerkandî, Tuhfetü'l-fukahâ', III, 104 vd.).

35 Cenâiz konuları Tuhfetüll-fukahâ'da da ayrı bir kitap olarak ele alınmıştır (Tuhfetülfukahâ', I, 239). 


\begin{tabular}{|c|c|c|c|}
\hline 8 & Kitâbü’n-Nikâh & 31 & Kitâbü’d-Dâ'vâ ve'l-beyyinât \\
\hline 9 & Kitâbü't-Talâk & 32 & Kitâbü’l-Vesâyâa ${ }^{36}$ \\
\hline 10 & Kitâbür-Radâ‘ & 33 & Kitâbü'l-Vekâle \\
\hline 11 & Kitâbü’l-'İded ${ }^{37}$ & 34 & Kitâbü'l-Kefâle \\
\hline 12 & Kitâbü’l-İtâk & 35 & Kitâbü’l-Havâle \\
\hline 13 & Kitâbü’l-Eymân & 36 & Kitâbü’s-Sulh \\
\hline 14 & Kitâbü’l-İcârât & 37 & Kitâbü’l-Müzâraa \\
\hline 15 & Kitâbü’ş-Şerike & 38 & Kitâbü'l-İkrâh \\
\hline 16 & Kitâbü'l-Mudârebe & 39 & Kitâbü'l-Kısmet \\
\hline 17 & Kitâbü’s-Sarf & 40 & Kitâbü'l-Me’zûn \\
\hline 18 & Kitâbü’r-Rehn & 41 & Kitâbü'l-İkrâr \\
\hline 19 & Kitâbü’ş-Şüf'a & 42 & Kitâbü’s-Siyer \\
\hline 20 & Kitâbü’z-Zebâih & 43 & Kitâbü’ş-Şirb \\
\hline 21 & Kitâbü’s-Sayd & 44 & Kitâbü'l-İbâha ve'l-hazr \\
\hline 22 & Kitâbü'l-Udhiye & 45 & Kitâbü’l-Eşribe ${ }^{38}$ \\
\hline 23 & Kitâbü’l-Gasb & 46 & Kitâbü'l-Keffârât ${ }^{39}$ \\
\hline
\end{tabular}

\section{Alt Başlıkların/Babların Tertibi}

Meseleci (kazüistik) bir yapıya sahip olan klasik fikıh kitapların bablarında yer alan mesâilin tertibinde belli bir düzen olmamakla birlikte, Kerhî gibi kelâm disiplininin kazandırdığı sistematik düşünce tarzına sahip fakihlerin telif ettiği metinlerde bab içindeki mesâil tertibinin daha derli toplu olduğu görülmektedir. el-Muhtasar’ın içinde yer alan kitapların hemen

36 Tuhfetü’l-fukahâda "vasiyet” kitabından önce "ikrar” kitabı gelmektedir (Tuhfetülfukahâ', III, $193 \mathrm{vd}$.).

37 "Radâ" ve "iddet" kitapları Tuhfetü'l-fukahâ'da "Kitâbü't-Talâk"ın altında birer bab olarak yer almaktadır (Tuhfetü'l-fukahồ, II, 235, 243).

38 "Eşribe" kitabı Tuhfetül-fukahâ'da "şürb" kitabından sonra gelmektedir (Tuhfetülfukahâ', III, $325 \mathrm{vd}$.).

39 "Keffârât" kitabı içinde yer alan konular Tuhfetül-fukahâ'da ilgili kitapların altında zikredilmiştir. Meselâ yemin kefâreti "eymân” kitabında yer alır (Tuhfetül-fukahâ', II, $341 \mathrm{vd}$.). 
hepsinde konuyla ilgili çeşitli bablar bulunmaktadır. Buralarda ana konunun alt bölümlerini oluşturan mesâil birbirinden ayrılarak belli bir sistematik içinde ele alınmaya çalışılmıştır. Meselâ aşağıda geleceği üzere ibadet bahislerindeki "farz, vâcip, sünnet" ayırımı ile muâmelât bahislerindeki tarif, taksim, şartlar, hükümler şeklindeki anlatım tarzının ilk örneklerine Kerhî̉nin el-Muhtasar'ında sıkça rastlamak mümkündür. Kirmânî, Kerhînin el-Muhtasar'ındaki tertibin iyi olup bablar içerisindeki mesâilin birbirine bağdaşık ve birbiriyle daha fazla insicam içinde olduğunu söyleyerek ${ }^{40}$ eserin bu yönüne dikkat çekmiştir.

\section{1. İbadetle İlgili Babların Tertibi}

"Tahâret, namaz, zekât, oruç, hac" kitaplarından oluşan ibadet konular1nın babları şu şekildedir:

Kerhî "tahâret" bahislerine "abdest, gusül ve teyemmüm" ile başlamış, sonrasında tahârette kullanılacak sular, bu suların yer aldığ kuyular ve kaplar, necâsetler ve bunların temizliği, derilerin tabaklanması, istincâ gibi konuları el-Asl'da olduğundan daha tertipli bir şekilde işlemiştir. Kerhî̀nin eksik bıraktığı anlaşılan mestler üzerine mesh gibi bazı konuları da Kudûrî tamamlamıştır. ${ }^{11}$ el-Muhtasar'ın "tahâret" kitabında, ilgili konunun farzlarının ve sünnetlerinin birbirinden ayrılması şeklinde bir metot takip edildiği görülmektedir. Meselâ Kerhî, "tahâret" kitabında "Abdestin farzları Allah’ın kitabında beyan ettiği şeylerdir" sözüyle ilgili âyete atıfta bulunarak abdestte yıkanması ve meshedilmesi farz olan âzaları sıralamakta, ardından gusül ve teyemmümün farzlarını açıklamaktadır. Sonrasında abdestin sünnetlerini sayarak, farzlarla sünnetleri birbirinden ayırmaktadır. ${ }^{42}$ Devamında da abdesti gerektiren halleri sayarak 43 "tahâret" kitabında farzlar-sünnetler-abdest/guslü gerektiren haller şeklinde bir sistematik oluşturmuş ve bu anlatım tarzı Kudûrî ve sonrasında yazılan bütün muhtasarlar tarafından benimsenerek geliştirilmiştir.

"Kitâbü’s-salât"ta mekruh vakitler, namazın kılınışı, namazın mekruhları, namazda kıraat ve miktarı, seferde, binek üzerinde, gemide namaz, cuma, bayram ve korku namazları, hastanın namazı, nâfile namazlar, vitir namazı, sehiv

40 Kirmânî, et-Tecrîd, Süleymaniye Ktp., Fâtih, nr. 178o, vr. o ${ }^{\mathrm{b}}$.

41 Kudûrî, Şerhu Muhtasari'l-Kerhî, nr. 93, vr. $22^{\mathrm{b}}-31^{\mathrm{b}}$. Kerhînin teyemmüm ve mestler üzerine mesh gibi bazı önemli konulara el-Muhtasar'da yer vermemesi, Kudûrînnin şerhin başında dediği gibi, eseri çok kısa bir muhtasar olsun diye telif etmeye başlamasıyla alâkalı olabilir.

42 Kudûrî, Şerhu Muhtasaril-Kerhî, nr. 93, vr. $2^{\mathrm{a}}, 3^{\mathrm{b}}, 4^{\mathrm{a}}$.

43 Kudûrî, Şerhu Muhtasari'l-Kerhî, nr. 93, vr. $5^{\mathrm{b}}$. 
secdesi, namazda abdestin bozulması gibi konular ele alınmıştır. ${ }^{44}$ Cenazeyle ilgili hükümler diğer muhtasarların aksine "kitâbü’s-salat"ın içinde değil de ondan sonra "kitâbü’l-cenâiz" başlığı altında ayrı olarak zikredilmektedir. ${ }^{45}$

Zekât kitabının başında kelimenin lugavî ve ıstılahî anlamı verildikten sonra "altın gümüş, ticaret malları ve hayvanların zekâtı, bunların verileceği yerler, alacakların zekâtı, zekât malının helâkı, çocuklara ve akıl hastalarına ait malların zekâtı, öşür, maden ve hazinelerin zekâtı, fitır sadakası" gibi konulara yer verilmektedir. ${ }^{46}$ Zekât konuları el-Asl'da "hayvanların zekâtı" ile başlarken ${ }^{47}$ Kerhî bu tertibi değiştirip "altın ve gümüşün zekâtı" ile konuya başlamıştır, fakat bu konuda kendisini sadece Tuhfetül'-fukahâ' sahibi Semerkandî takip etmiş, ${ }^{8}$ Kudûrî̀ ${ }^{49}$ ve diğer muhtasar sahipleri el-Asl'da olduğu gibi zekât konularına hayvanların zekâtıyla başlamayı tercih etmişlerdir. Kerhî fitır sadakası hükümlerini el-Aslda olduğu gibi oruç kitabında değil $5^{\circ 0}$ Tahâvî gibi zekât kitabında ${ }^{51}$ zikretmiş, Kudûrînnin de aynı tercihi devam ettirmesi sonucunda klasik dönemin muhtasarlarında "fitır sadakası babı" zekât kitabında yer almıştır. ${ }^{22}$

"Oruç" kitabı da kelimenin lugavî ve istılahî anlamıyla başlar. Sonrasında "orucun vakti, oruç tutma şartları, niyet, orucu bozan şeyler, oruç bozmayı veya tutmamayı meşru kılan özürler, orucun mekruhları, oruç tutmanın mekruh olduğu vakitler, kefâreti gerektiren durumlar, ramazan hilâlinin görünmesi" ve en son "itikâf" konularına yer verilir.53

"Menâsik/hac" kitabı da kelimenin lugavî ve ıstılahî tanımıyla başlar. Ardından "haccın kime farz olduğu, ihrama girilen mîkat sınırları, haccın yapilışı, haccın kaçırılması, hac çeşitleri, hacdan alıkonulma (ihsar), ihram yasakları, başkası adına hac, hacda kesilen kurban (hedy)" konuları tertipli bir şekilde incelenmiş, ${ }^{4}$ Kudûrî ve diğer muhtasarlar da hac konularını hemen bu tertip üzere anlatmışlardır. ${ }^{5}$

\footnotetext{
44 Kudûrî, Şerhu Muhtasaril-Kerhî, nr. 93, vr. $22^{\mathrm{b}}-31^{\mathrm{b}}$.

45 Kudûrî, Şerhu Muhtasari'l-Kerhî, nr. 563, vr. $49^{\mathrm{b}}-54^{\mathrm{b}}$.

46 Kudûrî, Şerhu Muhtasaril-Kerhî, nr. 563, vr. 55 a $-67^{\mathrm{a}}$.

47 Şeybânî, el-Asl, II, 54 vd.

48 Semerkandî, Tuhfetül-fukahâ', I, 264 vd.

49 Kudûrî, el-Muhtasar, s. 67 vd.

50 Şeybânî, el-Asl, II, 173.

51 Tahâvî, el-Muhtasar, s. 51-52.

52 Kudûrî, el-Muhtasar, s. 82-83.

53 Kudûrî, Şerhu Muhtasari'l-Kerhî, nr. 563, vr. $67^{\mathrm{a}}-75^{\mathrm{b}}$.

54 Kudûrî, Şerhu Muhtasari'l-Kerhî, nr. 563, vr. $75^{\mathrm{b}}-96^{\mathrm{b}}$.

55 Örnek olarak bk. Kudûrî, el-Muhtasar, s. 90-113.
} 
Kerhînin ibadetlerle ilgili konuların tertibine dair yukarıda kısaca izah edilen bab sistematiği Kudûrî ve onun vasıtasıyla diğer muhtasar sahipleri tarafından da benimsenerek ibadet konuları Hanefî muhtasarlarında genel olarak bu tertip üzerine işlenmiştir.

\subsection{Muâmelâtla İlgili Babların Tertibi}

Muâmelât konularının başında genellikle tarif, taksim ve şartlara yer verilerek konuya genel bir giriş yapılmakta, ardından da bahsedilen muâmelât akdinden doğan karşıllklı haklar ve yükümlülükler konu bütünlüğü içinde sıralanmaktadır. ${ }^{56}$ el-Muhtasar'in örnek incelemeye tâbi tutulan "icâre/kiralama" kitabında yer alan mesâilin genel olarak şöyle bir sistematik içerisinde sunulduğu görülmektedir:

Delil: Aşağıda geleceği üzere bölüme ilgili âyet ve hadislerle başlanıp konuya dair verilecek bazı genel hükümlerin âyet ve hadislerden temellendirmesi yapilır. ${ }^{57}$

Tarif: Konunun fikhî ahkâmına geçilmeden önce merkez kavramın tarifi yapılıp bir fikıh terimi olarak ne anlama geldiği açılklanır. ${ }^{8}$

Taksim: Delil ve tanımdan sonra ele alınan konunun türleri açıklanır ve bu açılklama ile tarifin bütün türleri içeren "efradını câmi" olduğu da zımnen ifade edilmiş olur. ${ }^{59}$

Şartlar: Metinde ele alınan akdin bütün türlerinde geçerli olan temel şartlar belirtilir. ${ }^{60}$

Hüküm: Genel şartların zikredilmesinden sonra konunun ana gövdesini oluşturan mesâile geçilir. Bu mesâil, yapılan akdin neticesinde doğan ve literatürde "akdin ahkâmı" ${ }^{61}$ başlı̆̆ı altında toplanan karşılıklı haklar ve yükümlülüklerdir. ${ }^{62}$

56 İcâre örneği için bk. Abdülmuhsin b. Abdullah, “Şerhu Muhtasari'l-Kerhî”, s. 12-37 vd.

57 Abdülmuhsin b. Abdullah, “Şerhu Muhtasari'l-Kerhî”, s. 4-6.

58 Abdülmuhsin b. Abdullah, "Şerhu Muhtasari'l-Kerhî”, s. 8.

59 Abdülmuhsin b. Abdullah, "Şerhu Muhtasari'l-Kerhî”, s. 8-9.

6o Meselâ Kerhî "icâre” bahsinde bir zâbıt zikrederek, icâre türlerinin hepsinde akde konu olan müstecerin, ücretin, akit süre üzerinden yapıldıysa sürenin, mesafe üzerinden yapıldıysa mesafenin ve iş üzerine yapıldıysa işin muhakkak belli olması gerektiğini akdin (sıhhat) şartı olarak ortaya koymaktadır (Abdülmuhsin b. Abdullah, "Şerhu Muhtasari'l-Kerhî”, s. 8).

61 Meselâ fikıh mesâilini belli bir sistematik içinde aktarmaya en fazla özen gösteren Hanefî fakihi olarak bilinen Kâsânî (ö. 587/1191) her bölümün başında olduğu gibi "icâre" bölümünün başında da ele alınacak konular arasında "akdin ahkâmı"nı da zikreder (Kâsânî, Bedâi, IV, 174).

62 Abdülmuhsin b. Abdullah, "Şerhu Muhtasari'l-Kerhî”, s. 12 vd. 
Taraflar arasındaki ihtilâflar: Akdin hükümlerinden sonra taraflar arasında vukuu muhtemel ihtilâflar ele alınarak bu ihtilâfların nasıl giderileceği üzerinde durulmaktadır. ${ }^{63}$

Akdin fesadı: Akdin gerekli şartlar muvacehesinde kurulmaması ve bu sebeple fâsit olması durumu ve durumun kendine has hükümleri konu edilmektedir. ${ }^{64}$

Akdin sona erdirilmesi veya ermesi/fesih ve infisah: Akdi sona erdiren veya erdirmeyi meşru kılan durumlardan bahsedilmektedir. ${ }^{65}$

Netice olarak Kerhînnin el-Muhtasar’ında muâmelât konuları söz konusu olduğunda yukarıda geçtiği üzere başta meşruiyet delili olmak üzere sırayla "tarif, taksim, şartlar, hükümler, ihtilâflar, akdin fesadı ve nihayet akdin sona ermesi veya erdirilmesi” şeklinde belli bir sistematiğin var olduğu söylenebilir. ${ }^{66}$ Onun konuların sunumuyla alâkalı yukarıda kısaca ifade edilen bu üslûbu delil zikretme kısmı hariç Kudûrî tarafından da benimsenerek klasik dönem muhtasar üslubunun oluşmasını sağlamıştır. ${ }^{67}$

63 Abdülmuhsin b. Abdullah, "Şerhu Muhtasari'l-Kerhî", s. 124 vd.

64 Abdülmuhsin b. Abdullah, "Şerhu Muhtasari'l-Kerhî”, s. 157 vd.

65 Abdülmuhsin b. Abdullah, “Şerhu Muhtasari'l-Kerhî”, s. 249 vd.

66 Fıkıh mesâilinin bu sistematik üzere işlenmesi daha sonraları Kerhînin el-Muhtasar’’ esas alınarak hazırlanan Tuhfetü'l-fukahâ' ve onun bir şerhi mahiyetinde olan Bedâiu'ssanâi i'de geliştirilerek mesâilin sunumu daha da sistematikleştiği gibi fikıh dili de çok daha zengin ve detaylı bir hale gelmiştir. Meselâ muâmelât konularında öncelikle akdin rüknü, sonra bu rüknün in'ikad, nefâz, sıhhat ve lüzum şartlarının ele alınması şeklinde bir metot geliștirilmiş, bu şartların bulunup bulunmamasına göre akitler mün'akit-bâtıl, nâfiz-mevkuf, sahih-fâsit, lâzım ve gayrilâzım diye isimlendirilmiştir (bk. Kâsânî, Bedâii, V, 233 vd.). Bu sistematik anlatım tarzının oluşmasında Kerhî̉den hemen sonra yaşamış olan Ebû Zeyd Abdullah (Ubeydullah) b. Muhammed edDebûsînin de (ö. 430/1039) katkıları olmuştur. Debûsî el-Esrâr isimli çalışmasıyla Hanefî fikıh literatürüne yeni kavramlar ve daha soyut taksim türleri kazandırmıştır. Meselâ Tuhfetü'l-fukahâ' ve Bedâiu's-sanâi'de görülen alışverişin dörderli iki farklı türe ayrımı asıl olarak el-Esrâr'da yer almaktadır (Krş. Özer, "Debbusi'nin 'el-Esrar fi'lUsul ve'l-Furu' Adlı Eserinin Tahkik ve Tahlili”, s. 736; Semerkandî, Tuhfetü'l-fukahâ', II, 7; Kâsânî, Bedâi', V, 134-35).

67 "İcâre" bölümü üzerinden Kerhînin el-Muhtasar'ı ile klasik dönemin meşhur muhtasarları (Muhtasarü'l-Kudûrî, Tuhfetü̉-fukahâ', el-Hidâye, el-Vikāye, el-Muhtâr, Kenzü'd-dekāik, Gurerül-ahkâm, Mülteka'l-ebhur ve Tenvîrül-ebsâr) arasında yapılan karşılaştırmanın bir tablosu için bk. Ençakar, “Kerhînnin Muhtasar'’”, s. 108-11. 


\section{C) Eserin Muhteva/Mesâil Açısından Tahlili}

\section{Fıkhî Mesâilin Naklî Delillerine Yer Verilmesi}

Muhtasarların yazılış gayeleri belli bir mezhebin görüşlerini en veciz şekilde ortaya koymak olduğundan Hanefî mezhebi muhtasarlarında genellikle delile yer verilmez. Özellikle klasik dönemin neredeyse şerhsiz anlaşılmayacak kadar lafızdan tasarruf eden muhtasarlarının temel özelliklerinden biri budur. ${ }^{68}$ Fakat Hanefî mezhebi teşekkül dönemi muhtasarları söz konusu olduğunda bu muhtasarların hem delil hem de mezhep içi ihtilâfları zikretme hususunda klasik dönem muhtasarlarından daha farklı oldukları görülmektedir. Kerhî el-Muhtasar’ında, "bu konudaki asıl" (el-aslü fî hâzâ) deyip âyet, hadis veya âsârdan delil zikrederek konuya girmeye özen gösterir. ${ }^{69}$ Kerhînnin zikretmiş olduğu bu deliller genellikle o bölüm boyunca Hanefî mezhebi adına ortaya koyacağı mesâilin esâsâtını teşkil eden naslardan oluşmaktadır.

Kerhînin bu konuda Şeybânîyi takip ettiği açıktır. Zira hem Şeybânînin el-Asl’nnda hem de onun muhtasarı Hâkim Şehîd'in el-Kâfîsinde genellikle konu başlarında ilgili âyet ve hadislere yer verilmektedir. Kudûrî ve sonrasında yazılan klasik dönem muhtasarlarında ise konuyla ilgili âyet ve hadislere neredeyse hiç yer verilmeyerek bu önemli bölüm ihmal edilmiştir. Hemen her konuda olduğu gibi bu konuda da Kudûrînin tavrının belirleyici olduğu; onun el-Muhtasar'ına aldığı konuların klasik dönem muhtasarlarında devam ettirildiği, almadığı konuların da ihmal edildiği görülmektedir. Bunun en belirgin örneklerinden biri konu başında zikredilen âyet ve hadislerdir.

\section{1. Âyetler}

Fıkıhta ele alınan mesâilin çoğu hadis, âsâr ve kıyas gibi delillere dayalı olup hakkında Kur'an'da sarih delil bulunan konular çok sınırlıdır. Bu sınırlı sayıda âyetin herkes tarafından bilindiği farzedilerek Hanefî fıkıh muhtasarlarında bu âyetlere pek yer verilmez. Kerhî diğer birçok konuda olduğu gibi bu konuda da farklı bir metot izleyip ilgili âyetleri zikretmeye özen göstermiştir. Meselâ ibadet bahislerinde "abdest, teyemmüm, namazın belli vakitlere tahsisi, cuma namazı, yağmur duası, tilâvet secdesi, cenazenin defni, zekât, zekâtın kimlere verileceği, öşür, oruç, itikâf ve hac" konularına, "Bu konuda şu âyet asıldır” diyerek başlar. Onun bu tavrından konuyu, herkes tarafından

68 Fıkıh muhtasarları ve özellikleriyle ilgili bk. Kaya, "el-Muhtasar", s. 61.

69 Kerhî birçok konuya bu şekilde başlar (örnek olarak bk. Kudûrî, Şerhu Muhtasari’lKerhî, nr. 563 , vr. $\left.19^{\mathrm{a}}, 55^{\mathrm{a}}, 57^{\mathrm{a}}, 57^{\mathrm{b}}, 63^{\mathrm{a}}, 74^{\mathrm{a}}\right)$. 
mutlak delil olarak kabul edilen Kur'an âyetleriyle temellendirmeyi kendisine bir prensip edindiği kanaatine varılabilir. ${ }^{70}$

\subsection{Hadisler ve Âsâr}

Kerhî yukarıda geçtiği üzere el-Muhtasar'inda $e l$-Aslda olduğu gibi -genellikle bölüm başlarında- konuyla ilgili hadisler ve âsâra yer vermektedir. Kāsım b. Kutluboğa (ö. 879/1474) onun eserlerinin bu özelliğine dikkat çekerek el-Câmiu's-sagìr, el-Câmiu'l-kebîr ve el-Muhtasar'inda senetleriyle birlikte hadis ve âsâr zikrettiğini nakleder. ${ }^{71}$ Talebelerinden Cessâs da (ö. 370/981) ondan senetli hadis rivayetinde bulunur. ${ }^{72}$ Fakat elimizdeki Kudûrî şerhinde bu rivayetler genellikle senetsizdir. ${ }^{73}$ Kāsım b. Kutluboğa’nın ifadeleri göz önünde bulundurulduğunda senet hazfinin şârih Kudûrîye ait bir tasarruf olma ihtimali yüksektir. Nitekim Kudûrînin "sarf" bahsinin başında el-Muhtasar'da geçen bir hadisi naklederken "Kerhî bu hadisin isnadını da zikretti" demesine rağmen isnadı vermemesi,74 ayrıca diğer bazı eserlerde Kerhî̀nin el-Muhtasar'ından yapılan hadis nakillerinde isnatların zikredilmesi ${ }^{75}$ senet hazfinin Kudûrî tarafından yapılmış olduğunu göstermektedir. Kerhî̉nin el-Muhtasar'da yer verdiği bazı rivayetleri Şeybânînnin eserlerinden almış olma ihtimali de vardır. Meselâ Kudûrî, Kerhînin rivayet ettiği bir hadis için, "Bu Muhammed'in zikrettiği uzun bir haberdir. ${ }^{76}$ Fakat Ebü'l-Hasan (Kerhî) bunu kısaltıp sadece konuyla ilgili bölümünü zikretmiş̦tir” demektedir.77 Bu ifadeden Kerhînin hadisi el-Asl'dan kısaltarak aldığı sonucu çıkarı-

70 Örnek olarak bk. Kudûrî, Şerhu Muhtasari'l-Kerhî, nr. 563, vr. $1^{\mathrm{a}}, 12^{\mathrm{b}}, 17^{\mathrm{a}}, 33^{\mathrm{a}}, 37^{\mathrm{b}}, 48^{\mathrm{a}}$, $55^{\mathrm{a}}, 59^{\mathrm{a}}, 63^{\mathrm{a}}, 67^{\mathrm{b}}, 74^{\mathrm{a}}, 75^{\mathrm{b}}$.

71 İbn Kutluboğa, Tâcü't-terâcim, s. 201.

72 Örnek olarak bk. Cessâs, Ahkâmü'l-Kur'ân, I, 17; III, 67, 346; a.mlf., Șerhu MuhtasaritTahâvî, I, 203, 594, 602-3, 712; II, 269-70.

73 Örnek olarak bk. Kudûrî, Şerhu Muhtasari'l-Kerhî, nr. 563, vr. 50 ${ }^{\mathrm{a}}, 57^{\mathrm{a}}, 57^{\mathrm{b}}, 61^{\mathrm{b}}$.

74 Abdülmuhsin b. Abdullah, "Şerhu Muhtasari'l-Kerhî", s. 682-83; Kudûrî, Şerhu Muhtasaril-Kerhî, nr. 563, vr. $259^{\mathrm{a}}$.

$75 \mathrm{Bu}$ rivayetlerden biri için bk. Mutarrizî, el-Muğrib, I, 135. Kerhînnin talebesi Ebû Abdullah el-Basrî̀den ders almış olan Zeydî fakih Müeyyed-Billâh Ahmed b. Hüseyin Şerhu't-Tecrîd isimli eserinde Kerhînin el-Muhtasar'ında yer alan bu rivayetlerden bir kısmını senetleriyle nakletmiş ve diğer bir kısmı için de Kerhînin bunları senediyle rivayet ettiğini söylemiş̧ir (Müeyyed-Billâh, Şerhu’t-Tecrîd, I, 448, 521; II, 353).

76 Şeybânî, el-Asl, III, 426. Şeybânî el-Asl’ın birçok kitabının başında o kitapta işleyeceği konulara delil olan rivayetlere yer vermektedir. Meselâ "icâre" kitabının başında merfû, mevkuf ve maktu' yirmiden fazla rivayet bulunmaktadır (Bk. el-Asl, III, 426433).

77 Abdülmuhsin b. Abdullah, “Şerhu Muhtasari'l-Kerhî”, s. 4-5; Kudûrî, Şerhu Muhtasari’lKerhî, nr. 563, vr. $223^{\mathrm{a}}$. 
labileceği gibi aynı hadisi kendi senediyle bu şekilde rivayet etmiş olması da muhtemeldir.

Bölüm başlarında aktardığı hadislerden anlaşıldı ğı üzere Kerhî, bir taraftan konunun en temel özelliklerine temas eden rivayetleri tercih ederken, diğer taraftan mezhep imamlarının kitaplarında mürsel olarak rivayet edilen bazı hadisleri müsnet olarak rivayet etmeye özen göstermektedir. ${ }^{78}$ Bunda, özellikle Irak'ta ehl-i hadis anlayışına sahip fıkıh çevrelerinin artan etkisinin önemli rol oynadığı söylenebilir.79

\section{Kavramlar}

\subsection{Kavramların Tanımı}

Kerhî, her yeni bölüme genellikle konunun temel kavramını tanımlayarak başlamaktadır. Müteahhirîn döneminde telif edilen geniş hacimli fikıh kitaplarında âdet haline gelen konu başında öncelikle kavramların lugavî ve ıstılahî anlamlarının verilmesinin Hanefî mezhebi fikıh literatürü tarihinde en erken örnekleri Kerhỉnin bu eserinde yer almakla birlikte bazı ıstılahî tanımların daha önce Şeybânînnin kitaplarında bulunduğu görülmektedir. Meselâ "ecîr-i müşterek" ve "ecîrürr-recül vahdeh" (ecîr-i hâs) kavramları bizzat el-Aslda ${ }^{80}$ mezhep imamları tarafından tarif edilmiş ve daha sonra birbirine yakın ifadelerle Tahâvî ve Kerhînnin muhtasarlarında yer almıştır. ${ }^{81}$

Kerhî tanımını yaptığı fikhî kavramlardan bir kısmının hem lugavî hem de ıstılahî anlamını verirken, diğer bir kısmının sadece ıstılahî anlamını vermekle yetinmiştir. Meselâ el-Muhtasar’ın zekât bahsinin başında, önce kelimenin lugavî anlamını verip ıstılahî anlamıyla alâkasını kurmakta, ardından kelimenin fikıhta kazandığı istılahî anlamı izah etmektedir. ${ }^{82}$ Oruç ve hac konularına da kelimenin lugavî ve ıstılahî mânasını vererek başlamıştır. ${ }^{83}$ Kerhî, muâmelât konularının model akdi olarak kabul edilen alışveriş akdinin temel kavramları mebî́ ve semenin de tarifini vermiştir: Mebîi (satılan mal) "akitle taayyün eden", semeni (ücret) de "akitle taayyün etmeyen" şeklinde

78 Örnek olarak bk. Abdülmuhsin b. Abdullah, “Şerhu Muhtasari'l-Kerhî”, s. 4-6; Kudûrî, Şerhu Muhtasaril-Kerhî, nr. 563, vr. 223 $3^{\mathrm{a}}$.

79 Ehl-i hadis fikıh anlayışının Hanefî mezhebi içindeki çalışmalara etkisi hakkında bk. Kaya, "Mezheblerin Teşekkülü" s. 142-51.

8o Şeybânî, el-Asl, III, 429-30.

81 Tahâvî, el-Muhtasar, s. 130; Abdülmuhsin b. Abdullah, "Şerhu Muhtasari'l-Kerhî̀, s. 53, 68; Kudûrî, Şerhu Muhtasari'l-Kerhî, nr. 563, vr. 225 a $225^{\mathrm{b}}$.

82 Kudûrî, Şerhu Muhtasaril-Kerhî, nr. 563, vr. 54 ${ }^{\mathrm{b}}$.

83 Kudûrî, Şerhu Muhtasari'l-Kerhî, nr. 563, vr. $67^{\mathrm{a}}, 75^{\mathrm{b}}$. 
tarif etmektedir. ${ }^{84}$ Kerhî diğer önemli bir muâmelât türü "icâre"yi (kiralama) de "âyanın menfaati üzerine yapılmış bir akit" olarak tanımlar. ${ }^{85} \mathrm{Bu}$ tanım müteahhirîn Hanefî fukahası tarafından benimsenip "efradını câmi“ ve ağyârı mâni'” olacak şekilde geliştirilmiştir. Kerhî̉nin fikhî kavramlara tanım getirmeye çalışması o dönemde yazılmış diğer iki muhtasar, Tahâvînin elMuhtasar’ı ile Hâkim Şehîd'in el-Kâfîsinde pek görülmeyen bir özelliktir. ${ }^{86}$

Kavramlara tanım getirme noktasında Kudûrî yer yer Kerhîyi takip etmiştir. Meselâ Kudûrî yukarıda geçen tanımlardan "icâre, ecîr-i hâs, ecîr-i müşterek"in tanımına yer verirken ${ }^{87}$ diğerlerini zikretmemiştir. Bundan, Kudûrînin sadece önemli olduğunu düşündügü tanımlara yer verdiği anlaşlmaktadır.

\subsection{Kavramların Geliştirilmesi}

Kerhînin el-Muhtasarı̀nda bazı kavramların el-Asl'da yer alan isminden farklı olarak zikredildiği de görülmektedir. Meselâ el-Asl'da "ecîr" (işçi türleri); "ecîr-i müşterek" (herkese çalışan) ve "ecîrü’r-recül vahde" (tek kişiye çalışan) şeklinde geçmektedir. ${ }^{88}$ İşçiler hakkındaki bu taksimin Kerhî̉nin elMuhtasar'ında "ecîr-i müşterek" ve "ecîr-i hâs" şeklinde geçip, "ecîrürr-recül vahde" terimi yerine, onunla aynı mânaya gelen; fakat daha teknik ve mâna açısından "ecîr-i müşterek" lafzının tam karşıtı olan "ecîr-i hâs" teriminin tercih edildiği görülmektedir. ${ }^{89}$ Kerhî̉nin bu konuda Tahâvîden faydalanmış olması da muhtemeldir. Zira Tahâvî el-Muhtasar'inda ecîr-i hâs terimini kullanmakta ve tıpkı el-Asl'da olduğu gibi tarifini de yapmaktadır..$^{90}$ Bununla birlikte Kerhî ve Tahâvînin yeni terimler oluşturma konusunda daha önceki kuşakların faaliyetlerinden faydalanmış olmaları da mümkündür.

\subsection{Yeni Kavramlar Üretilmesi}

Kerhînin el-Muhtasar'ında sonraki dönem muhtasarlarında farklı isimle anılan kavramlar da bulunmaktadır. Meselâ sonraları "farz-ı kifâye" şeklinde

84 Kudûrî, Şerhu Muhtasaril-Kerhî, nr. 563, vr. 103a .

85 Abdülmuhsin b. Abdullah, “Şerhu Muhtasari'l-Kerhî”, s. 8; nr. 563, vr. 223 $3^{\mathrm{a}}$.

86 Meselâ icârenin bu tarifi her iki muhtasarın ilgili bölümlerinde yer almamaktadır (bk. Tahâvî, el-Muhtasar, s. 128-32; Hâkim Şehîd, el-Kâfî, nr. 923, vr. 229 ${ }^{\mathrm{a}}-51^{\mathrm{b}}$ ).

87 Bk. Kudûrî, el-Muhtasar, s. 152, 154, 155.

88 Şeybânî, el-Asl, III, 561.

89 Abdülmuhsin b. Abdullah, “Şerhu Muhtasari'l-Kerhî”, s. 68; Kudûrî, Şerhu Muhtasari'lKerhî, nr. 563, vr. $225^{\mathrm{b}}$.

90 Tahâvî, el-Muhtasar, s. 129-30. 
terimleşecek olan, "bazı müslümanların yapmasıyla diğerlerinden sorumluluğun düştüğü; fakat topluca terkinin câiz olmadığı yükümlülükler" için Kerhî "vâcib fi'l-cümle"91 ve "vâcib mücmel"92 ifadesini kullanmakta ve yukarıda tercümesini verdiğimiz tarifi yapmaktadır. Bu ifadeden Kerhînin elMuhtasar’’ yazdığı dönemde, Hanefîler’ in farz ile vâcip ayırımının kavramsal varlığının henüz lafzî varlığa dönüşmediği; fakat her iki hüküm arasındaki farkı göstermek ihtiyacına binaen yeni kavramlar üretme yoluna gidildiği anlaşılmaktadır.93

\section{3. İşlenen Konunun Kısımlara Ayrılıp Türlerinin Belirlenmesi}

Kerhî bölüm başlarında konunun temel kavramını açıkladıktan sonra gerekiyorsa konuyu kısımlara ayırmakta ve mesâili bu kısımlara göre ele almaktadır. Böylece bu kavramın altında hangi türlerin yer aldığı, bu türlerin kendisine has ne tür şartları ve ahkâmı bulunduğunu anlama ve kavrama noktasında çok daha etkili bir üslûp kullanmaktadır.

Kerhînin bu özelliğine talebesi Cessâs da dikkat çekmiştir. Cessâs Tahâvînnin, "Yeminler üç kısımdır; kefâreti gerektiren, gerektirmeyen ve affı umulan" şeklindeki ifadesiyle yeminlerin hükmü üzerinden yaptığı taksimi şerhederken hocası Kerhînin bunu, "Yeminler iki kısımdır. Geçmişe ve geleceğe yönelik olanlar. Geçmişe yönelik olanlar da iki kısımdır: kasıtsız yanlış yere yapılan (lağv) ve kasitlı yalan yere yapılan (gāmûs) yeminlerdir. Kefâret sadece geleceğe yönelik yapılıp da tutulmayan yeminlerdedir. Yemîn-i lağvda ne kefâret ne de günah vardır. Yemîn-i gāmûsta kefâret olmasa da günah vardır” şeklinde açıkladığını söyleyerek hocasının konuyu hükme göre değil de meselenin daha iyi anlaşılmasını sağlayan hükmün illetine göre bir taksime tâbi tuttuğunu ifade etmek ister gibidir.94

Kerhînin konuyu bu şekilde hükme medar olan illete göre taksim etmesinin bir diğer güzel örneği icâre bahsinde yer almaktadır. Kerhî "icâre”yi "âyanın menfaati üzerine yapılmış bir akit" şeklinde tarif ettikten sonra kiralamada "bir şeyden faydalanma" veya "birinden bir işi yapmasını isteme" şeklinde iki türlü menfaat kullanımının söz konusu olduğunu söyleyerek bu

91 Kudûrî, Şerhu Muhtasari'l-Kerhî, nr. 563, vr. 51 b.

92 Güney, “Şerhu Muhtasari'l-Kerhî”, Arapça edisyon bölümü, s. 6.

93 Mu'tezilî usulcü Ebü’l-Hüseyin el-Basrî (ö. 436/1044), Kerhînin talebesi Ebû Abdullah el-Basrî̀den (ö. 369/980) nakille Bağdat ehlinin farz ile vâcip arasında ayırım yaptıklarını farzı, "vücûbiyeti kesin yolla sabit vâcip" olarak, farz anlamına gelmeyen vâcibi de, "vücûbiyeti zan ve emâre yoluyla sabit olan" şeklinde tarif ettiklerini aktarmaktadır (Ebü'l-Hüseyin el-Basrî, el-Mu'temed, I, 369).

94 Bk. Cessâs, Şerhu Muhtasarit'-Tahâvî, VII, 373. 
akdi temelde ikiye ayırır. Kudûrî şerhinde Kerhînin yaptığı bu taksimin doğru olduğunu söyleyip kiralama akitlerinin bu iki tür üzerinden yapıldığını vurgular. ${ }^{95}$ Kezâ şirket kitabının başında şirketlerin üç kısma ayrıldığını ve bu üç kısım şirketin her birinin de ayrıca iki ayrı çeşidinin söz konusu olduğunu söyleyen Kerhî, daha bahsin başında şirketleri üç ana gruba ayırmakta ve ardından her bir kısmın kendine has şartlarını ve mesâilini zikretmektedir. ${ }^{96}$ Kerhînin konuyu kısımlara ayırıp anlatmasına diğer bir örnek olarak madenlerin zekâtıyla ilgili yaptığı taksim gösterilebilir. O, topraktan çıkan madenleri, a. eriyen, b. akıcı ve c. ne eriyen ne de akıcı şeklinde üç gruba ayırıp ${ }^{97}$ hepsinin hükümlerini ayrı ayrı zikretmiş ve böylece mesâilin daha kolay anlaşılmasını sağlayan başarılı bir anlatım tarzı geliştirmiştir.

Kudûrînin, ele alınan konuyu kısımlara ayırıp türlerini belirlemede Kerhîyi takip etmediği görülmektedir. Zira Kudûrî el-Muhtasar’’nda yukarıda örnek olarak verilen madenlerin zekâtına hiç değinmezken, icâre bahsinde baştan herhangi bir taksime gitmemiş, şirket bahsinde konuyu taksime tâbi tutsa da burada Kerhîden farklı bir metot takip etmiştir.98

\section{Küllî Kaideler}

Kerhî̀nin biraz da kelâmcı kişiliğinden kaynaklanan önemli yönlerinden bir diğeri konu hakkında zikredeceği mesâili kuşatan asıl/zâbıtt99 zikretmesidir. Kendisinin imamlardan aktarılan mesâilin esasını oluşturan kaideleri (asılları) tespit edenlerin önde gelenlerinden biri olarak tebârüz ettiğ $i^{100}$ ve mezhebin sistemleştirilmesinde önemli katkıları olduğ ${ }^{101}$ bilinmektedir. Kerhî, mezhep mesâilinin ortak noktalarını keşfetme noktasında gösterdiği

95 Abdülmuhsin b. Abdullah, "Şerhu Muhtasari'l-Kerhî”, s. 8-10; Kudûrî, Şerhu Muhtasaril-Kerhî, nr. 563 , vr. $223^{\mathrm{a}}$.

96 Bk. Abdülmuhsin b. Abdullah, "Şerhu Muhtasari'l-Kerhî", s. 304; Kudûrî, Şerhu Muhtasari'l-Kerhî, nr. 563, vr. 230 ${ }^{\mathrm{b}}$. Kudûrî kendi muhtasarında bu taksimi biraz daha geliştirerek farklı bir şekilde vermiştir (bk. el-Muhtasar, s. 79).

97 Kudûrî, Şerhu Muhtasari'l-Kerhî, nr. 563, vr. $65^{\mathrm{a}}$.

98 Bk. Kudûrî, el-Muhtasar, s. 167.

99 "Zâbıt kelimesi yer yer kaide ile aynı anlamda kullanılmakla birlikte fakihlerin çoğunluğu kaideyi daha geniş, zâbıtı ise daha dar kapsamlı olarak görür ve aralarında fark bulunduğuna işaret ederler. Buna göre kaide muhtelif konulara dair meseleleri, zâbıt ise yalnız bir konuya dair meseleleri kuşatır. Meselâ "Bir işten maksat ne ise hüküm ona göredir" kaidesi (Mecelle, md. 2) "bey', hibe, havale, kefâlet" gibi fikhın bütün konularına uygulanabilme imkânı taşırken, "İcârede ma'kūdün aleyh menfaattir" cümlesi bir zâbıt olup sadece icâre bahsine mahsustur" (Baktır, "Kaide", s. 205). Burada zâbıt terimiyle kastedilen de kelimenin bu dar anlamıdır.

100 Kaya, "Mezheblerin Teșekkülü”, s. 218, 230-35.

101 Apaydın, "Kerhî”, s. 285. 
bu çabasıyla birçok meseleyi tek bir asıl altında toplayarak hem o mesâilin kolayca anlaşılıp akılda tutulmasına hem de sistematik fikıh anlayışının gelişimine katkıda bulunmuştur.

el-Muhtasar'da zikredilen zâbit/asillar genellikle "küllü...,", 102 "el-aslü fî", ${ }^{103}$ "el-aslüll-lezî", ${ }^{104}$ "hâze'l-bâbü mebniyyün alâ aslınâ,", 105 "aslü hâze’l-bâb",106 "cümletü mâ"107 veya "ve cümletü hâze'l-bâb"108 gibi ifadelerle başlayan cümleler içinde verilmektedir. Hemen her konuya dair asıllar zikretmeye özen gösteren Kerhî bu yönüyle de diğer muhtasarlarda pek rastlanamayacak farklı bir telif üslûbuna sahip olduğunu göstermiştir.

Kudûrînnin bu konuda Kerhîden faydalandığ zaman zaman onun zikrettiği bu küllî kaidelere yer verdiği görülmektedir. ${ }^{109}$

\section{Mezhep İmamlarının Görüşleri}

Kerhî mezhep imamlarının görüşlerini aktarma konusunda Şeybânînin kitaplarında takip ettiğine benzer bir prensibi benimsemiştir. Şeybânî elAsl’nn başında, "kitapta Ebû Hanîfe, Ebû Yûsuf (ö. 182/798) ve kendi görüşlerini belirttiğini, ihtilâf zikretmediği yerde o görüşün üçüne ait olduğunu" söylemiştir. ${ }^{110}$ Kerhînnin de el-Muhtasar'ında bu üç imamın görüşlerini vermeye çalıştı̆̆ 1 , ihtilâf olmayan yerlerde tıpkı el-Asldaki gibi isim vermeden veya "inde ashâbinâ", "111 "kāle ashâbünâ cemîan", 112 "fî kavlihim cemîan"113 türü ifadelerle meseleyi sunduğu görülür. Meselede ihtilâf olduğunda ise

\footnotetext{
102 Kudûrî, Şerhu Muhtasari'l-Kerhî, nr. 563, vr. $8^{\mathrm{a}}, 10^{\mathrm{a}}, 12^{\mathrm{a}}, 43^{\mathrm{b}}, 71^{\mathrm{a}}, 120^{\mathrm{a}}, 123^{\mathrm{b}}$.

103 Kudûrî, Şerhu Muhtasari'l-Kerhî, nr. 563, vr. $58^{\text {b. }}$

104 Kudûrî, Şerhu Muhtasari'l-Kerhî, nr. 563, vr. $61^{\mathrm{b}}$.

105 Kudûrî, Şerhu Muhtasari'l-Kerhî, nr. 563, vr. 56 ${ }^{\mathrm{b}}$.

106 Kudûrî, Şerhu Muhtasari'l-Kerhî, nr. 563, vr. $11^{\mathrm{a}}$.

107 Kudûrî, Şerhu Muhtasari'l-Kerhî, nr. 563, vr. 106 ${ }^{\mathrm{a}}, 107^{\mathrm{a}}$.

108 Âdil b. Abdullah, "Şerhu Muhtasari'l-Kerhî”, s. 112; Kudûrî, Şerhu Muhtasari'l-Kerhî, nr. 563, vr. 71 a . Yazma nüshada bu ifadelerin yer aldığ kısımlarda bazan sadece "kāleşşeyh" bazan da "kāleş̧-şeyh Ebü’l-Hasan" denilmektedir. "Kāleş-şeyh" ifadelerinin el-Muhtasar’ın şârihi Kudûrîye ait olma ihtimalinden dolayı diğer fikıh kitaplarından yapılan tarama sonucunda kitapta bu ifadeyle gelen açılamaların büyük oranla Kerhîye nispet edildiği görülmüş ve bu sebeple "kāleş-şeyh" ifadesiyle gelen açıklamalar Kerhî̀ye ait kabul edilmiştir.

109 "İcâre" bahsindeki küllî kaidelere örnek olarak bk. Kudûrî, el-Muhtasar, s. 152, 153, 157, 158.

110 Şeybânî, el-Asl, I, 5.

111 Abdülmuhsin b. Abdullah, "Şerhu Muhtasari'l-Kerhî”, s. 92.

112 Abdülmuhsin b. Abdullah, "Şerhu Muhtasari'l-Kerhî”, s. 239.

113 Abdülmuhsin b. Abdullah, “Şerhu Muhtasari'l-Kerhî”, s. 981.
} 
genellikle yine el-Asl'da olduğu gibi önce varsa Ebû Hanîfe’nin sonra da Ebû Yûsuf'un ve Şeybânînin görüşlerini verir. ${ }^{114}$ Bazan da Ebû Hanîfe'nin diğer iki öğrencisi Züfer (ö. 158/775) ve Hasan b. Ziyâd’’n (ö. 204/819) görüşlerine, hatta nâdiren de olsa mezhep dışına çıkarak Hammâd b. Ebû Süleyman (ö. 120/738) gibi Ebû Hanîfe’nin hocaları silsilesinden ${ }^{15}$ veya İbn Ebû Leylâ (ö. $148 / 765)^{116}$ gibi diğer Kûfe fukahasından meşhur simaların görüşlerine yer verebilmektedir. Kerhînin diğer fakihlerden getirdiği görüşleri, daha ziyade Ebû Hanîfe'nin tek kaldığı yerlerde onun görüşünü güçlendirmek için zikrettiği anlaşılmaktadır. ${ }^{117}$

Teşekkül dönemi muhtasarlarında yer alan bu özellik Kudûrî ile birlikte terkedilmeye başlamıştır. Kudûrî ihtilâflı konularda mezhep imamlarının hepsinin görüşlerini her zaman vermeyip bazan sadece tercih edilen görüşü zikretmekle yetinmiştir. Kudûrî sonrasında yazılan el-Muhtâr, el-Vikāye, enNukāye ve Kenzü̉d-dekāik gibi klasik dönem muhtasarlarında ise genellikle Ebu Hanîfe'nin görüşü tercih edilip onunla yetinilmiş yahut el-Muhtâr veya Kenzü'd-dekāik'te olduğu gibi diğer imamların ihtilâfına sadece rumuzla işaret edilmiştir. ${ }^{118}$

\section{Zâhirü'r-rivâye ve Gayru zâhiri'r-rivâye Mesâili}

Hanefî mezhebinde ilk muhtasarların ortaya çıktı̆̆ IV. (X.) asrın ilk yarısına kadar geçen yaklaşık iki asırlık sürede mezhep mesâilinin öğrenilmesi imamlardan aktarılan Usûl ve Câmiayn (zâhirü’r-rivâye), Emâlî ve Nevâdir (gayru zâhiriłr-rivâye) rivayetlerinin ayrı metinler içinde bir önceki nesilden tevarüs edilmesi şeklinde gerçekleşmiştir. IV. (X.) asrın ilk yarısında ortaya çıkan teşekkül dönemi muhtasarlarında bu rivayetler bir kompozisyon içerisinde fakat birbirine karıştırılmadan ele alınmaya başlamıştır. Her ne kadar bugün elimizde mevcut olan el-Aslın bazı bölümlerinin sonunda o bölümle ilgili nevâdir mesâiline yer verilse de ${ }^{119}$ bu muhtasarlarda olduğu gibi her

114 Örnek olarak bk. Abdülmuhsin b. Abdullah, "Şerhu Muhtasari'l-Kerhî”, s. 53, 100, 158, 169.

115 Abdülmuhsin b. Abdullah, "Şerhu muhtasari'l-Kerhî”, s. 53.

116 Abdülmuhsin b. Abdullah, "Şerhu muhtasari'l-Kerhî”, s. 773.

$117 \mathrm{Bu}$ yerlere örnek olarak bk. Abdülmuhsin b. Abdullah, "Şerhu Muhtasari'l-Kerhî”, s. 53, 158; Kudûrî, Şerhu Muhtasari'l-Kerhî, nr. 563, vr. 114'; Güney, "Şerhu Muhtasari’lKerhî”, s. 76.

118 Klasik dönem metinlerinde Ebû Hanîfe’nin görüşüyle yetinilmesiyle alâkalı olarak bk. Ençakar, "Kerhî̉nin Muhtasar'”', s. 12, 15-16, 18, 20, 29-31.

119 Meselâ $e l-A s l ı n$ Mehmet Boynukalın tarafından yapılan neşrinde, "kitâbü’s-savm"ın sonunda Ebû Hanîfẻnin talebelerinden Hasan b. Ziyâd'ın (ö. 204/819) Mücerred'inden bazı bölümler ve "nevâdirü’s-savm" adı altında el-Asl’ın râvilerinden Ebû Süleyman 
iki rivayet türünün (zâhirürr-rivâye ve gayru zâhirìr-rivâye) bölüm içerisinde ele alınarak değerlendirildiği bir kompozisyon türü ilk muhtasarların çıktığı döneme kadar söz konusu değildir. Bu durum, muhtasarları ayrıcalıklı kılan yönlerden bir diğeridir. Böylece ilk defa mezhep imamlarına ait bütün mesâil topluca bir değerlendirmeye tâbi tutularak tek bir metin içinde ele alınmıştır. ${ }^{120}$ İfade edildiği üzere Kerhî el-Muhtasar’ında sadece imamların görüşlerini aktaran bir râvi konumunda değildir. Aksine ele almış olduğu konu hakkında imamların son veya rivayet açısından en doğru görüşlerini tespit etmeye çalışmaktadır. ${ }^{121}$ Ayrıca "zâhirü’r-rivâye"de (Usûl ve Câmiayn) yer almayıp "gayru zâhirìr-rivâye"de (Emâlî ve Nevâdir) geçen ${ }^{122}$ veya imamların görüşlerine kıyas/tahriçle zikredilmiş ${ }^{123}$ mesâile de yer vererek konunun eksik taraflarını tamamlama gayreti içindedir. Kerhî, bu yaptığ 1 ile ele aldığı konuyu mezhep içinde geldiği son haliyle tek bir kompozisyon içinde sunmaya çalışan bir müellif görüntüsü vermektedir.

Mezhep imamlarından "zâhirürr-rivâye" dışında aktarılan görüşlerin kaynaklarının muhtasarlarda açıkça ifade edilmesi teşekkül dönemi muhtasarlarına has olup klasik dönemi muhtasarlarında bu tutum terkedilerek zâhirürrivâye dışından gelen rivayetlerin kaynağını zikretmeye ihtiyaç duyulmamış, böylece her iki rivayet türü aynı metinde birbirinden ayrılmadan nakledilmeye başlamıştır. Diğer birç̧ok konuda olduğu gibi bu konuda da öncülük eden kişi Kudûrî olmuştur. O kendisinden önce yazılan teşekkül dönemi muhtasarlarının aksine kendi el-Muhtasar’ında zikrettiği rivayetleri herhangi bir sınıflamaya tâbi tutmamış ve böylece klasik dönem muhtasarlarında yer alan görüşler, hangisinin "zâhirür-rivâye" hangisinin "gayru zâhiri’r-rivâye" olduğuna veya hangisinin bizzat mezhep imamlarının görüşleri olduğuna ve hangisinin de onların görüşlerine kıyasla tahriç edildiğine bakılmaksızın zikredilmeye başlamıştır.

\section{Mezhep İmamlarina Muhalefet}

Son olarak Kerhînnin el-Muhtasar'da nâdiren de olsa mezhep imamlarına muhalefet ettiğini belirtmek gerekir. Meselâ fâsit icâre (kiralama) akitlerini anlatırken, buğday ve zeytinyağı gibi mekîlât ve mevzûnâtın ağırlık

el-Cûzcânînin Şeybânîden rivayet ettiği bazı mesâil bulunmaktadır. Kitabı neşreden Boynukalın bu bölümlerin el-Asldan olmayıp Ebû Süleyman el-Cûzcânî veya bazı râviler tarafından eklenmiş olduğunu; fakat kitabın bütün nüshalarında bulunduğu için köşeli parantez içinde bunları da neşrettiğini söylemektedir (Bk. el-Asl, II, 202, 205).

120 Konuyla ilgili olarak ayrıca bk. Kaya, "Mezheplerin Teşekkülü”, s. 176.

121 Meselâ bk. Abdülmuhsin b. Abdullah, “Şerhu Muhtasari'l-Kerhî”, s. 20, 22, 546, 597, 725.

122 Meselâ bk. Abdülmuhsin b. Abdullah, "Şerhu Muhtasari'l-Kerhî”, s. 330.

123 Meselâ bk. Abdülmuhsin b. Abdullah, "Şerhu Muhtasari'l-Kerhî”, s. 6o, 180. 
ölçüsü olarak kullanılmak üzere kiralanmasının câiz olmadığını söylemektedir. ${ }^{124}$ Kudûrî bu meseleyi şerhederken Şeybânînin el-Asl'da ${ }^{125}$ mekîlât ve mevzûnâtın bu amaçla kiralanmasının câiz olduğunu belirttiği halde Kerhî̉nin câiz görmediğini söyler. Sonra da hocası Ebû Abdullah Muhammed b. Yahyâ el-Cürcânînin (ö. 398/10o8) iki görüşün arasını cemetmek için yaptığı izahı verir. ${ }^{126}$ Diğer bazı muhalefet örneklerini ise Kerhî̀nin talebesi Cessâs (ö. 370/981) vermektedir. Cessâs hocasının nikâhta denklik konusunda mezhep imamlarından nakledilen "nesep ve sanatta denkliği" kabul etmediğini, gerekçe olarak da, "Kısasta herkes birbirine denktir. Öyleyse nikâhta da denk olmalıdır. Nikâhta denklik aranacaksa bu mehir ve nafakada olmalıdır" dediğini nakleder. ${ }^{127}$ Kerhînin mezhep imamlarına muhalefet ettiği bir diğer mesele sarhoşun talâkıyla alâkalıdır. Kerhî, sarhoşun talâkını akıl hastasının talâkına kıyas edip geçerli saymaz. ${ }^{128}$ Cessâs'n hocasından aktardığı diğer farklı bir görüş ise cemaatle namazı farz-ı kifâi olarak görmesidir. ${ }^{129}$

\section{Sonuç}

Kerhînin bugün için kayıp olup Kudûrî tarafından yapılan şerhi üzerinden takip edilen el-Muhtasar'ının şekil ve muhteva açısından tahlil ve Kudûrînin el-Muhtasar'ı üzerinden diğer muhtasar metinlere etkisinin konu edildiği bu makalede şu sonuçlara varılmıştır. Eser, bölüm başlarında konuyla ilgili âyet, hadis ve âsâra yer vermesi, fikhî kavramlara tanım getirmesi, konuyu taksime tâbi tutup her bir kısmın şartlarını zikretmesi, küllî kaide ve zâbıtlar tespit ederek konuyu belli bir sistematik içinde ele alması yönüyle Hanefî muhtasar geleneği içinde özel bir konumu ihraz etmiştir. Bunun dışında aynı dönemde telif edilen diğer iki muhtasarda olduğu gibi mezhep içi ihtilâfll meselelerde öncelikle Ebû Hanîfe sonra Ebû Yûsuf ve Şeybânînin görüşlerine yer vermesi, "zâhirü’r-rivâye" dışında kalan rivayetlerin kaynaklarını belirtmesi, imamların görüşleriyle o görüşlerden tahriç yoluyla elde edilen diğer görüşleri birbirinden ayırması, ayrıca Kudûrî ve sonrasında telif edilen klasik dönem muhtasarlarına göre daha hacimli olması açılarından da sonraki muhtasarlardan farklılık arzetmektedir.

\footnotetext{
124 Abdülmuhsin b. Abdullah, “Şerhu Muhtasari'l-Kerhî”, s. 185.

125 Şeybânî, el-Asl, IV, 11.

126 Abdülmuhsin b. Abdullah, “Şerhu Muhtasari'l-Kerhî”, s. 186.

127 Cessâs, Şerhu Muhtasari't-Tahâvî, IV, 255.

128 Cessâs, Şerhu Muhtasarit-Tahâvî, V, 16.

129 Cessâs, Ahkâmül-Kurân, IV, 204-5.
} 
el-Muhtasar’ın en önemli özelliği olarak Hanefî mezhebi fikıh mesâilini o döneme göre oldukça sistematik sayılabilecek bir şekilde sunması gösterilebilir. Bunda Kerhî̉nin kelâmcı kişiliğinin etkisi olduğu açıktır. el-Muhtasar'ın makale boyunca işaret edilen bu sistematiği daha sonraları Kudûrî aracılığı ile mezhebin diğer meşhur muhtasar sahipleri tarafından da benimsenerek özellikle tarif, taksim, şart ve küllî kaide zikretme noktasında geliştirilerek devam ettirilmiştir. Kerhîden bu yönden en çok etkilenen ve onun bu sistematik anlatım tarzını metinler bazında ileriye taşıyan kişinin Alâeddin esSemerkandî olduğu söylenebilir. O Tuhfetüll-fukahẩ isimli eserini Kerhî̉nin el-Muhtasar'ını esas alarak hazırlamış ve Debûsîden de istifade ederek bu sistematiği geliştirmiştir. Ardından damadı Kâsânî Tuhfetüll-fukahẩnın bir tür şerhi sayılan Bedâiu's-sanâi' isimli eserinde bu tarzı daha da geliştirerek sistematik fıkıh çalışmalarına önemli katkı sağlayan ender şahsiyetler arasındaki yerini almıştır.

\section{Bibliyografya}

Abdülmuhsin b. Abdullah, "Şerhu Muhtasari'l-Kerhî li-Ebi'l-Hüseyn el-Kudûrî min evveli kitâbi'l-icârât ilâ âhiri kitâbi’r-rehn” (doktora tezi), Câmiatü’l-İmâm Muhammed b. Suûd el-İslâmiyye, 1429.

Âdil b. Abdullah, “Şerhu Muhtasari'l-Kerhî li-Ebi'l-Hüseyn el-Kudûrî min evveli kitâbi'lhudûd ilâ nihâyeti kitâbi'l-havâle” (doktora tezi), Câmiatü'l-İmâm Muhammed b. Suûd el-İslâmiyye Riyad, 1429-30/2008-2009.

Apaydın, H. Yunus, “Kerhî”, Türkiye Diyanet Vakfı İslâm Ansiklopedisi (DİA), XXV, 285-87.

Aybakan, Bilal, "Furu' Fıkıh Sistematiği Üzerine”, Marmara Üniversitesi İlâhiyat Fakültesi Dergisi (MÜİFD), 31 (2006): 5-32.

Baktır, Mustafa, "Kaide”, DİA, XXIV, 205-10.

Bardakoğlu, Ali, “Hanefî Mezhebi”, DİA, XVI, 1-21.

Bedir, Murteza, "Hanefî Mezhebinin Abbâsî Bağdat'ında Yükselişi ve Zayıflaması", İslam Medeniyetinde Bağdat (Medînetü's-selâm) Uluslararası Sempozyumu: 7-9 Kasım 20o8, ed. İsmail Safa Üstün, I-II, İstanbul: Marmara Üniversitesi İlâhiyat Fakültesi Vakfı, 2011, I, 621-632.

Boynukalın, Mehmet, İmam Muhammed b. Hasan eş-Şeybânînin Kitâbu'l-Asl Adlı Eserinin Tanıtımı ve Fıkıh Usulü Açısından Tahlîli, İstanbul: Ocak Yayınları, 2009.

Cessâs, Ahkâmüll-Kurân, haz. Muhammed Sâdık Kamhâvî, I-V, Beyrut: Dâru ihyâi'ttürâsi'l-Arabî, 1405.

Cessâs, Şerhu Muhtasarit'-Tahâvî fi'l-fkhi'l-Hanefî̀, haz. Sâid Bekdâş v.dğr., I-VIII, Beyrut: Dârü'l-beşâiri'l-İslâmiyye, 1431/2010. 
Ebû Süleyman, Abdülvehhâb İbrâhim, Tertîbüll-mevzûâtil-fikhiyye ve münâsebetühû filmezâhibil-erbaa, Mekke: Câmiatü Ümmi'l-kurâ, 1408/1988.

Ebü'l-Hüseyin el-Basrî, el-Mu'temed fì usûli'l-fikh, haz. Muhammed Hamîdullah, I-II, D1maşk: el-Ma hedü'l-ilmî el-Fransî li’d-dirâsâti'l-Arabî, 1384/1964.

Ençakar, Orhan, “Kerhî̉nin Muhtasar'ının Hanefî Muhtasar Geleneğine Etkisi: Kudûrînin Muhtasar’ının İcâre Bölümü Çerçevesinde” (yüksek lisans tezi), Marmara Üniversitesi, İstanbul, 2013.

Güney, Necmeddin, “Kudûrînin ‘Şerhu Muhtasari’l-Kerhî’ Adlı Eserinin 'Siyer’ Bölümünün Edisyon Kritiği” (yüksek lisans tezi), Selçuk Üniversitesi, Konya, 2006.

Hâkim Şehîd, el-Kâfî, Millet Ktp., Feyzullah Efendi, nr. 922; Süleymaniye Ktp., Hacı Beşir Ağa, nr. 288.

İbn Kutluboğa, Tâcü̉t-terâcim, haz. M. Hayr Ramazan Yûsuf, Dımaşk-Beyrut: Dârü'lkalem, 1413/1992.

Kâsânî, Bedâiu's-sanâi fî̀ tertîbişs-şerâi', I-VII, Beyrut: Dârüll-kütübi'l-ilmiyye, 1406/1986.

Kâtib Çelebî, Keşfü̉z-zunûn an esâmi'l-kütüb ve’l-fünûn, haz. Şerafettin Yaltkaya - Rifat Bilge, I-II, Beyrut: Dâru ihyâi't-türâsi'l-Arabî, ts.

Kaya, Eyyüp Said, “Hanefî Mezhebinde Nevâzil Literatürünün Doğuşu ve Ebu'l-Leys esSemerkandî̉nin Kitabu'n-Nevâzil'i', (yüksek lisans tezi), Marmara Üniversitesi, İstanbul, 1996.

Kaya, Eyyüp Said, “Mezheblerin Teşekkülünden Sonra Fıkhî İstidlâl” (doktora tezi), Marmara Üniversitesi, İstanbul, 2001.

Kaya, Eyyüp Said, “Muhtasar”, DİA, XXXI, 61-62.

Kirmânî, Rükneddin, el-1̂zâh, Süleymaniye Ktp., Cârullah Efendi, nr. 586.

Kirmânî, Rükneddin, et-Tecrîd, Süleymaniye Ktp., Fâtih, nr. 1780.

Kudûrî, el-Muhtasar, haz. Sâid Bekdâş, Beyrut: Dârü'l-beşâiri'l-İ̀lâmiyye, 1431/2010.

Kudûrî, Şerhu Muhtasari’l-Kerhî, Köprülü Ktp., Fâzıl Ahmed Paşa, nr. 93; Süleymaniye Ktp., Damad İbrâhim Paşa, nr. 563.

Makdisi, George, Ortaçağda Yüksek Öğretim, çev. Ali Hakan Çavuşoğlu - Hasan Tuncay Başoğlu, İstanbul: Gelenek Yayıncılık, 2012.

Molla Hüsrev, Dürerül-hükkâm fî şerhi Gureril-ahkâm, I-II, İstanbul: Şirket-i Sahafiye-i Osmaniye, 1317.

Mutarrizî, el-Muğrib fî tertîbi'l-Mu'rib, haz. Mahmûd Fâhûrî - Abdülhamîd Muhtâr, I-II, Halep: Mektebetü Üsâme b. Zeyd, 1399/1979.

Müeyyed Billâh, Ahmed b. Hüseyin, Șerhu't-Tecrîd fî fikhi'z-Zeydiyye, haz. M. Yahyâ Sâlim Azzân - Hamîd Câbir Ubeyd, I-VI, Saná Merkezü’t-türâs ve'l-buhûsi'l-Yemenî, 2006/1427.

Müzenî, Muhtasarül-Müzenî, haz. M. Abdülkādir Şâhin, Beyrut: Dârü’l-kütübi'l-ilmiyye, 1419/1998.

Nedîm, Ebü'l-Ferec Muhammed b. İshak, el-Fihrist, haz. Eymen Fuâd Seyyid, I-III, London: Müessesetü’l-furkān, 1430/2009. 
Nûh b. Mustafa, Netâicü’n-nazar, Süleymaniye Ktp., Esad Efendi, nr. 653-654.

Özen, Şükrü, Ebû Mansûr el-Mâtürîdînin Fıkıh Usûlünün Yeniden İnşası, İstanbul: y.y., 2001.

Özer, Salim, “Debbusi'nin 'el-Esrar fi'l-Usul ve'l-Furu' Adlı Eserinin Tahkik ve Tahlili”" (doktora tezi), Erciyes Üniversitesi, Kayseri, 1997.

Saymerî, Hüseyin b. Ali, Ahbâru Ebî Hanîfe ve ashâbih, Beyrut: Âlemü'l-kütüb, 1405/1985.

Semerkandî, Alâeddin, Tuhfetüll-fukahâ', I-III, Beyrut: Dârü’l-kütübi'l-ilmiyye, 1405/1984.

Sezgin, Fuat, Târîhu't-türâsil-Arabî, çev. Mahmûd Fehmî Hicâzî v.dğr., VIII, Riyad: Câmiatü’l-İmâm Muhammed b. Suûd el-İslâmiyye, 1411/1991.

Şeybânî, Muhammed b. Hasan, el-Asl, haz. Mehmet Boynukalın, I-XII, Beyrut: Dâru İbn Hazm, 1423/2012.

Şeyh Nizâm v.dğr., el-Fetâva’l-Hindiyye, I-VI, Bulak: el-Matbaatü'l-Emîriyye, 1310.

Tahâvî, el-Muhtasar, haz. Ebü’l-Vefâ el-Efgānî, Kahire: Dârü'l-kütübi'l-Arabî, 1370.

\begin{abstract}
Hanefî Fıkıh Literatüründe Gelenek Oluşturan Kayıp Bir Metin: Muhtasarü’lKerhî

Mezhep imamlarından aktarılan fıkıh mesâilini kısa ve öz olarak tek bir metinde toplamalarının sağladığı kolaylıkla tedris faaliyetlerinde tercih sebebi olan muhtasarlar, belli bir dönem sonra mezhep mesâilinin gelecek nesillere aktarılmasında birinci el kaynaklar haline gelmişlerdir. Bu muhtasarlardan biri de Hanefî mezhebi teşekkül dönemi ilk muhtasar müelliflerinden ve dönemin Bağdat Hanefîleri’nin reisi Kerhînin el-Muhtasar'ıdır. Eser, Hanefî mezhebi klasik dönem muhtasarlarının model metni Kudûrîye ait el-Muhtasar’ın da temel kaynağıdır. Kerhînnin usule dair görüşleri mezhebin usûl-i fikıh anlayışında etkili olduğu gibi, fikha dair telif ettiği bu eseri de Kudûrînin el-Muhtasar’ı üzerinden mezhebin klasik dönem muhtasar metinlerine yön vermiştir.
\end{abstract}

Anahtar Kelimeler: Kerhî, el-Muhtasar, Hanefîlik, teşekkül dönemi. 